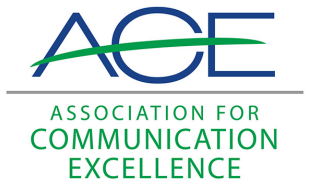

Journal of Applied Communications

\title{
No Time for Modesty; Is Anyone Watching?; Are You Experiencing Burnout? ; Public Relations: Editors Rate Pillsbury, ADA and DAY Top PR Operations
}

Jim Shaner

Linda Benedict

Follow this and additional works at: https://newprairiepress.org/jac

(c) (†)

This work is licensed under a Creative Commons Attribution-Noncommercial-Share Alike 4.0 License.

\section{Recommended Citation}

Shaner, Jim and Benedict, Linda (1986) "No Time for Modesty; Is Anyone Watching?; Are You Experiencing Burnout? ; Public Relations: Editors Rate Pillsbury, ADA and DAY Top PR Operations," Journal of Applied Communications: Vol. 69: Iss. 3. https://doi.org/10.4148/1051-0834.1620

This Review is brought to you for free and open access by New Prairie Press. It has been accepted for inclusion in Journal of Applied Communications by an authorized administrator of New Prairie Press. For more information, please contact cads@k-state.edu. 


\title{
No Time for Modesty; Is Anyone Watching?; Are You Experiencing Burnout? ; Public Relations: Editors Rate Pillsbury, ADA and DAY Top PR Operations
}

\author{
Abstract \\ Reviews of "No Time for Modesty," by Kirk A. Astroth and Benny S. Robbins; "Is Anyone Watching?" by \\ Mary Beth Lang, Kristine L. Blacklock, and Boyd E. Rossing; "Are You Experiencing Burnout?" by O. Chris \\ Igodan and L.H. Newcomb; "Public Relations: Editors Rate Pillsbury, ADA and DAY Top PR Operations," by \\ Dick Elfenbein.
}




\section{Reviews}

Today's emphasis on marketing extension, together with some of its consequences, is reflected in three articles from the last two issues of the Journal of Extension.

Jim Shaner

University of Missouri-Columbia

“'No Time for Modesty." Kirk A. Astroth and Benny S. Robbins in the Journal of Extension, Spring, 1986, pp. 21-24.

Setting the stage, "No Time for Modesty" chronicles the events that led government officials and others to scrutinize extension in the first place. One response was to do more to earn urban tax dollars. But Astroth and Robbins suggest we not target to any one group, rural or urban. Rather than targeting specific audiences, they stress building extension's visibility to all audiences.

For example, the authors note that most school children (and, perhaps more importantly, their parents) do not know the chick embryology projects in their schools are extension sponsored. So Astroth and Robbins conclude: "Ours is not an audience problem. . . it is an image problem."

"Rather than thinking of programs targeted to specific audiences, perhaps we need to make ourselves and our existing programs more visible to all audiences," they continue, "regardless of socioeconomic, geographic, or ethnic labels. This isn't a new idea, but the notion of becoming better advertisers may be."

Astroth and Robbins list six awareness steps for developing a better extension image:

1) "United we stand"-support each other's programs and promote them. 2) "Cooperate with other agencies"-

emphasizes the awareness developed that way for $4-\mathrm{H}$, with a local Chamber of Commerce, Job Service, Kiwanis Club and school districts, through working with them on youth programs. 3) "Use local media"--tells extension agents to do the things we tell them to do-write news releases, localize, drop by the mdeia, etc. 4) "Take credit"- -tells agents to "let organizations know when extension is providing resources, time, talents, and personnel for a particular program or seg- 
ment." Astroth and Robbins' suggestions include stamping all extension handouts with the name of the county office. They define extension as "the locally funded informal education program for the county." 5) "Don't be shy"-make the extension emblem conspicuous. Be seen, be heard. 6) "A penny spent is a dollar earned"-let the public know how much value they receive from extension professionals. The authors use the 4-H example in terms of the numbers of volunteers, man hours, dollars spent on $4-\mathrm{H}$ projects, mileage, etc.

Similar documentation might be available from extension Homemaker Associations and other efforts.

However, Astroth and Robbins' Kansas example may have been their best one: one county there broke the extension part of the budget into a percentage of the rest $(.022 \%$ !). They then calculated that the average county family spends $\$ 3$ for the entire extension program-" "only one-fifth of one cent for each tax dollar collected."

\section{“'Is Anyone Watching?'” Mary Beth Lang, Kristine L. Blacklock, and Boyd E. Rossing, in the Journal of Exten- sion, Summer, 1986, pp. 7-10.}

These three Wisconsin researchers examined cable television's use by extension. During the survey, Trempealeau County Community Television (TCCTV) was cablecasting from 11 a.m. to 2 p.m. Monday through Friday and from 6 p.m. to 8 p.m. Monday through Wednesday. Lang, Blacklock, and Rossing did nearly 240 telephone interviews of a random sampling of subscribers.

University of Wisconsin agents in Trempealeau County cablecast these programs during the survey: "Down to Earth," the agricultural agent's weekly lawn and garden program; "Clover Corner," the 4-H youth agent's weekly highlights of the county's 4-H program; "Home and Family Spotlight," the home economist's regular program; and "Community Comments," the county resource agent's occasional program.

Results of the Lang, Blacklock, and Rossing study showed a majority watched the four programs "once in a while." Roughly 15 percent watched the weekly "Down to Earth" and "Clover Corners" programs each week. Those using the information numbered 33 percent for both "Down to Earth" and 
"Home and Family Spotlight" and 17 percent for "Community Comments." Two thirds of the respondents said they understood the 4-H program better from watching "Clover Corners." Eighty percent said they either had been on the program or knew someone who had been. This implies, the researchers wrote, that "many viewers may be friends or family members of 4-Hers who participated in the events that were taped."

Viewer involvement and support, Lang, Blacklock, and Rossing said, was shown by the 60 percent who either had been on a program or knew someone who was, by the 20 percent who indicated the programming was a "very important" part of their cable service or the two thirds who rated it at neutral or above, and by the willingness of 70 percent to pay an extra $25 \$$ a month to keep extension programming.

They conclude:

- Cable can provide a way to reach large rural audiences.

- Local access viewers do not differ, significantly, from average cable viewers.

- Local access viewers will watch extension programs.

- Those viewers frequently use extension's information.

- Viewers consider community access programming an important part of their cable service.

For successful extension programming Lang, Blacklock, and Rossing list as requirements: 1) Strong local identification with local access cable; other agencies also presented programming. 2) Potential to reach a large number of residents: the cable system extension used reached 63 percent of the county's households. Working with a number of different county cable systems can be more difficult, they caution. 3) Community commitment to local access programming: the county system had regular daytime and evening programming, a full-time production manager to help in producing programs, and a program schedule published in local TV listings.

"Without adequate equipment, staff, and program support, using cable television can be extremely difficult," Lang, Blacklock, and Rossing conclude.

In a related article, "TV PSAs-Making Them Effective," pp. 29-30, Betty Youngman, an extension family life specialist at the University of Arkansas-Little Rock, lists nine steps in producing successful PSAs. She also lists six suggestions extension agents can follow to make PSAs more effective locally, and she presents the TV script of a PSA. This short 
article would make a terrific handout that television specialists can use with their extension clients.

\section{“Are You Experiencing Burnout?" O. Chris Igodan and L.H. Newcomb in the Journal of Extension, Spring, 1986, pp. 4-7.}

If your state and field staffs are clamoring for more coverage, under the delusion that more is always better, you may be experiencing burnout. Igodan and Newcomb write that physical symptoms range from exhaustion and stomach problems to hypertension and sexual dysfunction. Their list of 24 psychological symptoms includes: rigidity to change, apathy, loss of emotional control, suspicion/paranoia, and high risk-taking.

Behavioral symptoms on the job range from low job performance to workaholism. At home they include withdrawal, drug or alcohol use, and increased family conflicts. The authors offer these coping strategies: Be realistic-know what you're feeling and why. . . set realistic goals. . . recognize these and other symptoms of stress and burnout. . . ask for help when needed. . . develop a structural and personal support system. . . and retain hope.

Also, develop a detached concern for your clients. . . maintain an active social life outside of work. . . take timeouts. . . maintain proper nutrition and exercise. . develop a sense of organizational involvement. . . accept counseling when needed. . . develop "self-therapies"-meditation, biofeedback, relaxation response... and accentuate the positive.

Jim Shaner

University of Missouri-Columbia

\section{"Public Relations: Editors Rate Pillsbury, ADA and DAY Top PR Operations.' Dick Elfenbein in Editor and Publisher, February 15, 1986, pp. 15-16.}

If your mailing lists for press releases don't include newspaper food editors, then perhaps you should add them. According to the results of a recent study published in the February 15 issue of Editor and Publisher, these editors gave 
the highest marks to the releases received from state and local government agencies, including the argicultural extension service and county agent offices.

Of the 11 possible information sources listed in a questionnaire completed by 133 food editors, 86 percent rate state and local government offices as the most favored. Next in ranking, 81 percent, were educational institutions. The third through eleventh rankings were as follows: restaurants, press release file, local stores, food company PR people, specialized food media, trade associations, cooking schools, previously published materials and PR agency people.

The study was conducted by E\&P to assess food editors' attitudes toward PR efforts. The article said 26 percent of all food editors at U.S. newspapers replied to the five-page, 200-part questionnaire "about what they want from PR sources, what they get, what they use, their complaints and kudos."

Overall, food editors, who are typically understaffed, were receptive to press releases. They said press releases made their job of putting together a weekly food section easier. Even if they didn't use the press releases, they often got ideas from them.

They also liked receiving black-and-white and color photographs, recipes, surveys, trend releases, and household tips.

They didn't like follow-up phone calls to find out if they received a release. The article quoted Jane Snow of the Akron (Ohio) Beacon-Journal: "PR folks have become a major problem for food writers. They apparently all went to the same seminar where they were told to follow up on their releases by phoning food editors to make sure they received them. I don't have time to talk to PR folks. Usually, I don't remember their releases anyway."

The message? Keep those cards and letters coming, but hold off on the follow-up phone calls. 